\title{
Moringa oleifera: a promising agricultural crop and of social inclusion for Brazil and semi-arid regions for the production of energetic biomass (biodiesel and briquettes)
}

\author{
Francisco Sávio Gomes Pereira ${ }^{1, *}$, Antonio Demóstenes de Sobral ${ }^{2}$, \\ Ana Maria Ribeiro Bastos da Silva ${ }^{2}$ and Maria Aparecida Guilherme da Rocha ${ }^{3}$ \\ ${ }^{1}$ Federal Institute of Education, Science and Technology of Pernambuco-IFPE, Campi Recife and Ipojuca, Pernambuco, Brazil \\ ${ }^{2}$ Federal University of Pernambuco-UFPE, Center of Technology and Geosciences, Department of Chemical Engineering, Recife, \\ Pernambuco, Brazil \\ ${ }^{3}$ Federal University of Pernambuco-UFPE, Coordination of Science Teaching of Northeast-CECINE, Recife, Pernambuco, Brazil
}

Received 30 June 2017 - Accepted 3 October 2017

\begin{abstract}
This study describes properties of biomasses of Moringa oleifera Lamarck for energetic applications of production of biodiesel and briquettes. The seeds collected of the mature pods were the initial biomasses used of this plant. The seeds were separated into husks and oilseed grains, from which the oils were extracted by mechanical pressing and by solvent extraction. The crude oil mixed (of pressing and by solvent) was degummed, neutralized, washed, dried and characterized. The purified oil was converted into methyl biodiesel in homogeneous alkaline transesterification, which was purified and characterized. The residual peels and pies had their calorific powers measured and compared with classic agricultural residues: firewood, sugarcane bagasse and coconut husks. Moringa culture was compared to soybeans in agricultural and biodiesel production perspectives. The analytical results show that the biomasses of the moringa are favorable as renewable biofuels like biodiesel or briquettes due to the good calorific power and simple and accessible productive technology. The production of briquettes starting from the biomasses of the moringa would be recommended with the uses of the pod husks, seed peels and pies (cakes) of extraction of the oil. The agricultural management and the simple productive technologies applied to the moringa are favorable for social inclusion by enabling family agriculture.
\end{abstract}

Keywords: biomass / briquettes / biodiesel / moringa oil / transesterification

\begin{abstract}
Résumé - Moringa oleifera : une culture agricole prometteuse et d'inclusion sociale pour le Brésil et les régions semi-arides, pour la production de biomasse énergétique (biodiesel et briquettes). Cette étude décrit les propriétés des biomasses de Moringa oleifera Lamarck pour les applications énergétiques de production de biodiesel et de briquettes. Les graines collectées des gousses matures de cette plante étaient les biomasses initiales utilisées. Les graines ont été séparées en coques et graines oléagineuses, à partir desquelles les huiles ont été extraites par pressage mécanique et par extraction au solvant. L'huile brute mélangée (de pressage et par solvant) a été dégommée, neutralisée, lavée, séchée et caractérisée. L'huile purifiée a été convertie en biodiesel de méthyle dans une trans-estérification alcaline homogène, qui a été purifiée et caractérisée. Les puissances calorifiques des tourteaux résiduels ont été mesurées et comparées aux résidus agricoles classiques : bois de chauffage, bagasse de la canne à sucre et coques de noix de coco. La culture de moringa a été comparée à celle du soja dans les perspectives de production agricole et biodiesel. Les résultats analytiques montrent que les biomasses de moringa sont favorables en tant que biocarburants renouvelables comme le biodiesel ou les briquettes en raison du bon pouvoir calorifique et de la technologie de production à la fois simple et accessible. La production de briquettes à partir des biomasses de moringa serait recommandée, valorisant ainsi les coquilles, pépins de graines et tourteaux générés par l'extraction de l'huile. La gestion agricole et les technologies productives simples appliquées à moringa sont favorables à l'inclusion sociale en favorisant l'agriculture familiale.
\end{abstract}

Mots clés : biomasse / briquettes / biodiesel / huile de moringa / trans-estérification

\footnotetext{
* Correspondence: cientista.francisco@yahoo.com.br
} 


\section{Introduction}

The publication "Sustainable Energy for All" (2015), a global initiative of the United Nations (UN) and the World Bank, addresses three development goals by 2030 :

- ensure universal access to electricity and modern energy services;

- duplicate the rate of energy efficiency improvement;

- to bend the share of renewable energy in the world energy matrix. These goals were endorsed at the United Nations General Assembly in 2011. The year 2012 also was declared by the UN as the year of Sustainable Energy for All. The Decade 2014-2024 has been declared as Sustainable Energy for All. The world consumption in 2012 of final energy by source was $79.4 \%$ of fossil, $18.1 \%$ of renewable and $2.5 \%$ (nuclear and others). The renewable sources include traditional and modern solid fuels, liquid fuels, biogas, wind, solar, geothermal and water (IEA, 2015).

The origin Moringa oleifera Lamarck is mentioned as a culture that dates from ancient times, coming from Agra and Oudh in India, south of the Himalayas (Foidl et al., 2001) and belongs to the family Moringaceae, of unique genus, with 13 different species, being the most cultivated. It was used by ancient Romans, Greeks and Egyptians (use of extracted oil for food and cosmetics) and is now widely cultivated in all tropical and subtropical regions of the world (Fahey, 2005). It is a perennial species, widely distributed in India, Egypt, Philippines, Ceylon, Thailand, Malaysia, Burma, Pakistan, Singapore, Jamaica, Nigeria, and other regions of the world (Ramachandran et al., 1980). It receives some special names in different regions: English (drumstick tree, horseradish tree, mother's best friend), Spanish (ben, árbol del ben, morango, moringa) and French (benzolive, moringa). In Brazil, it is known as cedar, white lily, okra of quina, moringa, white acacia, horse radish and moringueiro (Amaya et al., 1992). Its diffusion is linked to the colonial empires of the nineteenth century. At the end of the 19th century, it was introduced in Central America (Guatemala) by Haiti (Cáceres et al., 1991). In Brazil, the introduction of the tree has been timid, because the ornamentation in public parks was limited. Long ago, people in the Indian subcontinent have been using the pods of moringa in their feed. Leaves are used for feeding in West Africa and parts of Asia (Morton, 1991). It is currently widely cultivated and has become typical of many tropical regions and is an important crop in countries such as Ethiopia, Philippines, Sudan, Eastern Africa, Western Africa and South Africa, tropical Asia, Latin America, the Caribbean, Florida and Islands of Pacific (Fahey, 2005). In Brazil, it known in the State of Maranhão since 1950 and has been used as an ornamental plant, due to the lack of knowledge about its use as a vegetable, and is currently widespread throughout the Northeast of this country (Amaya et al., 1992).

Moringa oleifera is cultivated because of its food value (leaves, green fruits, flowers and toasted seeds); forage (leaves, fruits and seeds); medicinal (all parts of the plant); seasoning (mainly roots) and culinary; in the cosmetics industry (oil extracted from the seeds); meliferous (flowers); fuels (wood and oil) and in the treatment of water for human consumption (cotyledons and seed coatings) (Jahn, 1989; Morton, 1991).
The production rates of a tree are verified within 3 years of planting and can produce from 1000-1600 pods per year with an average of 24000 seeds. Frequent pruning of the treetops is able to maintain and increase leaf growth and height control to facilitate harvesting of the pods (Araújo, 2010). Its cultivation can be carried out in arid, semi-arid and hot areas with optimum temperatures between 25 and $35^{\circ} \mathrm{C}$, being able to tolerate momentary up to $48^{\circ} \mathrm{C}$ and weak frosts in the subtropical zones (HDRA, 2002). It is tolerant to drought and develops with annual precipitations between 250 and $3000 \mathrm{~mm}$ at altitudes below $600 \mathrm{~m}$ (Fuglie, 2001). It grows on soils with $\mathrm{pH}$ between 5.0 and 9.0, but prefers the neutral and welldrained soils (Crosby, 2007). It adapts better in well-drained clay-sandy soils and tolerates clayey soils without stagnant water. It is not demanding in terms of fertility, it also grows on poor soils and begins to flower 8 months after planting (Fuglie, 2001). It has taken a great importance in the production of biodiesel because it is one of the vegetal species with a great content in oil (average of 35\%). In one hectare of land can be planted between 700 and 1100 trees of moringa that initiate the production of fruits, generators seeds, at 12 months (Foidl et al., 2001). Its cultivation has an approximate yield of $2500 \mathrm{~kg} / \mathrm{ha}$, with $1478 \mathrm{~L} / \mathrm{ha}$ of oil and a biodiesel conversion factor of 0.96 , estimating a production of $1419 \mathrm{~L} / \mathrm{ha}$ of biodiesel (Foidl and Mayorga, 2000).

Biodiesel is widely used as an alternative fuel in various countries for their presented similar physico-chemical properties to conventional diesel, with the main advantage of reducing harmful pollutants such as sulphur and others pollutants (Pereira et al., 2016d). Biodiesel is a mixture of short chain esters, produced from fatty acids with varying numbers of carbon atoms, usually between 8 and 22. In practice such esters are obtained from a reaction denominated of transesterification (Schuler et al., 2016). It can be produced by various technologies such as homogeneous catalytic transesterification (acidic, basic or mixed), heterogeneous catalytic transesterification (acidic, basic or with natural resources), enzymatic transesterification, ultrasonic and microwave assisted transesterification, supercritical and membrane technologies and by reactive distillation (Aransiola et al., 2014). All these technologies are capable of producing biodiesel from refined oil, which is the most common source of raw material for that fuel. However, not all are able to generate biofuel from a less purified raw material (Marchetti, 2012). This product is an environmentally friendly alternative fuel, but usually has a higher price than mineral diesel. Its cost varies depending on the stock of feedstock, geographical area, variability in crop production depending on the season, crude oil price, among other factors (Kegl et al., 2013). Many resources coming from animals and from plants (mainly) can be used as feedstocks for biodiesel production. Depending on availability and production, they can be classified into three main categories: oleaginous plants, animal fats and fatty wastes mainly cooking oil recycled. It is important that the source has two requirements: low cost and large-scale production (Ahmad et al., 2013). The most predominant route for biodiesel production (alkaline transesterification) consists in the reaction of triacylglycerol rich (vegetable oils or animal fats) feedstocks with a short-chain alcohol (methanol or ethanol) in the presence of a basic catalyst, having fatty acid esters (Biodiesel) as products and glycerol (Glycerin) as a 
co-product. In Brazil, the feedstocks more used in the biodiesel production are: soybean oil, beef tallow and cottonseed oil (Pereira et al., 2016a).

The briquette is an ecological (recycled) firewood resulting from the process of drying and pressing (briquetting) sawdust or dust from the most diverse types of wood and forest and industrial wastes with combustible characteristics. The briquette is suitable for use in industrial boilers and also to replace with great efficiency the use of common wood, fuel oil and natural gas. The bio-briquette uses agro-industrial residues. Briquetting is a process of compaction of agricultural and industrial waste that can be divided into five steps: preparation, reagent mixing, heat treatment, pre-compaction and compaction, for the production of briquettes or pellets (ecological firewood) (Pereira et al., 2015).

The Moringa oleifera, known as the "tree of life", can be a sustainable renewable alternative for Brazil and regions with semi-arid climate and not very fertile soils. In this context, this study investigated the energetic potential of biomasses produced from the seeds of this plant with the purpose of producing biodiesel and briquettes in a sustainable productive chain.

\section{Materials and methods}

\subsection{Biomasses of study, applied treatments and analytical characterizations}

The investigated biomasses of Moringa oleifera are shown in Figure 1. The pods were harvested in their complete stage of maturation (visual evaluation - brown coloration). The collected pods were selected and cleaned with a brush to eliminate coarse particles adhered and opened to obtain the seeds. The seeds were separated in peels and oleaginous grains (kernel of seeds). The extraction of the oil was done by mechanical pressing and extraction with hexane in Soxhlet apparatus using the oleaginous grains of the seeds (Pereira et al., 2016a). The mixed crude oil was purified by degumming, neutralization, washing and drying treatments (Pereira et al., 2016c). The crude and purified oils were characterized in the analytical parameters: acidity index, peroxide index, saponification index, iodine value, specific mass, kinematic viscosity and water content. The chromatographic characterization of the moringa oil was also realized (Pereira et al., 2016b).

The purified mixed oil, molar mass $892.99 \mathrm{~g} / \mathrm{mol}$, was used as feedstock for the production of methyl biodiesel. Methanol, potassium hydroxide and anhydrous sodium sulfate, all of analytical grade were used as complementary inputs. The experiments (biodiesel production) were carried out under the conditions: $6: 1$ molar ratio (methanol:oil), $60{ }^{\circ} \mathrm{C}, 60$ minutes, $0.8 \%$ potassium hydroxide and agitation of the reaction medium at $300 \mathrm{rpm}$ (bottle with three mouths, coupled with hydraulic seal, thermometer and reflux condenser). The biodiesel produced (light phase) was decanted (decantation funnel) for 4 hours and separated of the glycerin impure (dense phase), washed with phosphoric acid solution and distilled water, dried with anhydrous sodium sulfate and vacuum filtered (Pereira et al., 2015, 2016a).

Purified biodiesel (methyl esters of moringa oil) was analyzed in: specific mass, kinematic viscosity, acidity index, water content, glycerol, monoacylglycerols, diacylglycerols and triacylglycerols and ester content (Pereira et al., 2015, 2016a,b).

In order to determine the purity and the biodiesel yield, its molar mass was calculated based on the centesimal composition determined by gas chromatography coupled with mass spectrometer from the transesterification of the moringa oil of this study. This analysis also served to determine the profile of fatty acids present in moringa oil (Pereira, 2015; Pereira et al., 2016b).

The determination of the higher calorific value of the samples serves to quantify the energy potential available in these biomasses. Analyzes of the moisture content and ash content of the samples should be performed to assist in assessing possible applications of biomass as alternative fuels. The parameters analyzed for energy purposes were: higher calorific value, lower calorific value, moisture content (for solid samples: seeds, oleaginous grains, peels and pies), ash content and water content by Karl Fischer (for liquid samples: crude oils, purified oil and biodiesel) (Pereira, 2015; Pereira et al., 2016b).

\section{Results and discussion}

\subsection{Yields of oil extraction and analytical characterizations}

The extractive yield by mechanical pressing was $11.36 \%$ (Pereira et al., 2016a) and below results found in the literature, such as 19\% (Parrotta, 2009) and 25.8\% (Tsaknis et al., 1999). This result is mainly due to the extractor used (artisanal and simplified); heterogeneities in the samples collected (trees of different sites and cultures); irregularity in the time of pod maturation and loss of material by volatilization (operational error). The extraction becomes more viable when are used industrial extruders with technological resources and heating associated. Despite this limitation in the extraction, the oil is of excellent sensory quality (light yellow color and fruity odor) and good fluidity (Pereira et al., 2016a).

The extractive yield by solvent was $36.48 \%$ (Pereira et al., 2016a) and very effective in oil percentages and very similar to several studies in the literature, such as 34.5\% (Goja, 2013), 35.7\% (Tsaknis et al., 1999), 40.0\% (Oliveira et al., 2012), 40.4\% (Anwar and Bhanger, 2003) and 41\% (Domínguez et al., 2017).

Table 1 shows the results of the analytical parameters: specific mass, kinematic viscosity, acidity index, peroxide index, saponification index, iodine value, turbidity and water content for the moringa oils (crudes, mixed crude and mixed purified) and Table 2 shows the fatty profile of moringa oil, after esterification (Pereira et al., 2016b).

Specific masses (Tab. 1) for the moringa oils are between $970.2 \mathrm{~kg} . \mathrm{m}^{-3}$ (solvent extraction) and $909.5 \mathrm{~kg} . \mathrm{m}^{-3}$ (mechanical pressing), and $970.0 \mathrm{~kg} \cdot \mathrm{m}^{-3}$ (mixed purified oil) at $40^{\circ} \mathrm{C}$, with a constant tendency of reduction when using extraction by solvent. The experimental values show that the solvent and treatments used slightly reduce the specific mass of the oil, which can be explained through the removal of impurities scattered present in the fatty structures of the glycerides (major components) (Pereira et al., 2016b). 
(a)

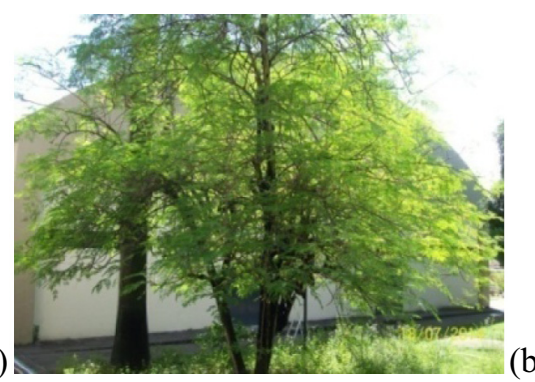

(d)

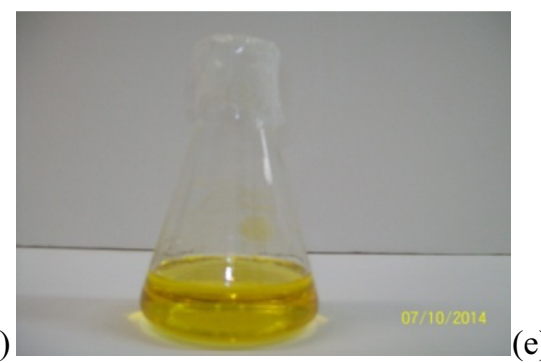

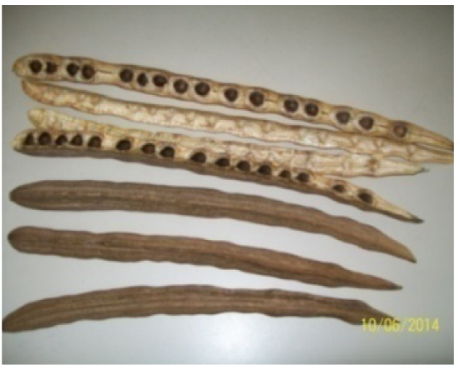

(c)
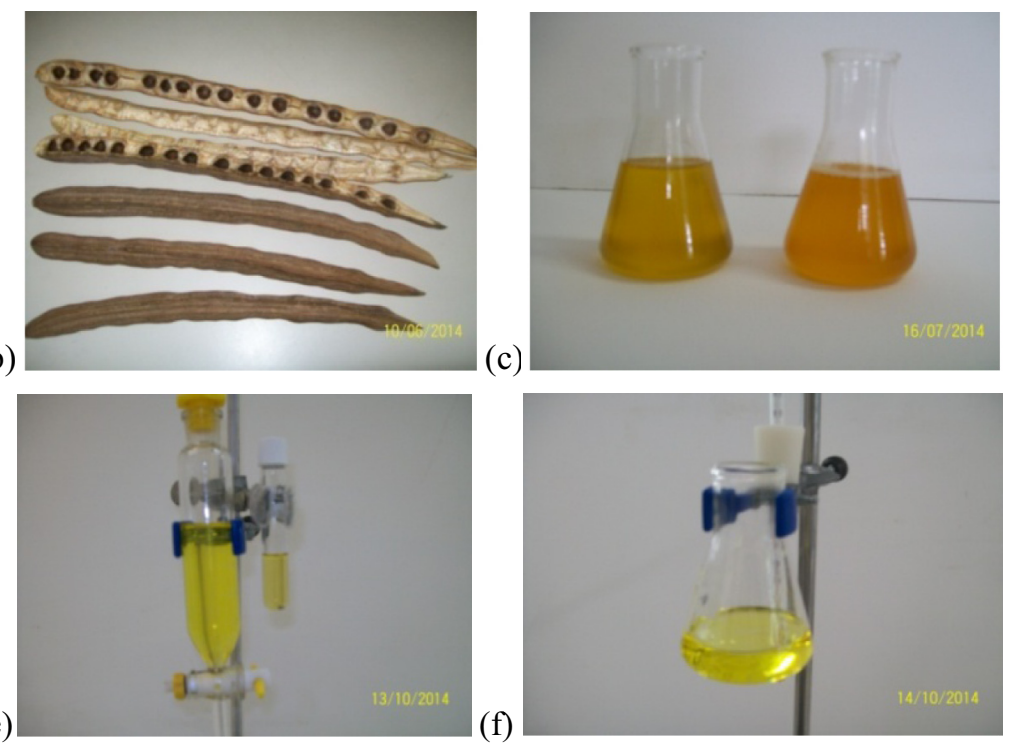

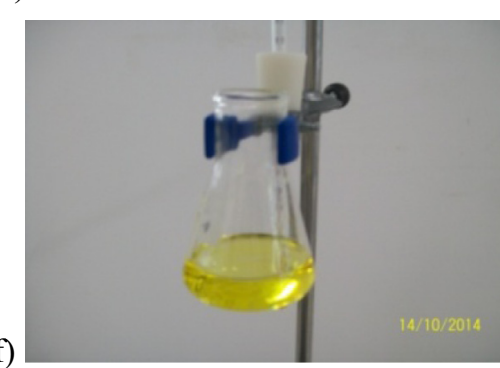

Fig. 1. Moringa oleifera and some derived biomasses; (a) one of the plants used in the collection of pods; (b) mature pods open and closed with seeds (30 to $40 \mathrm{~cm}$ ); (c) crude oils of pressing (left) and by solvent (right); (d) purified mixed oil; (e) biodiesel impure (left) and glycerin impure; (f) purified biodiesel.

Table 1. Analytical parameters of the investigated moringa oils.

Analytical parameters investigated/Methods and standards used

\begin{tabular}{|c|c|c|c|c|}
\hline & \\
\hline & $\begin{array}{l}\text { Mechanical } \\
\text { pressing oil }\end{array}$ & $\begin{array}{l}\text { Solvent } \\
\text { extracted oil }\end{array}$ & $\begin{array}{l}\text { Mixed } \\
\text { crude oil }\end{array}$ & $\begin{array}{l}\text { Mixed } \\
\text { purified oil }\end{array}$ \\
\hline Specific mass $\left(\mathrm{kg} / \mathrm{m}^{3}\right.$ at $\left.20^{\circ} \mathrm{C}\right)(\mathrm{NBR} 14065 / \mathrm{ASTM}$ D4052) & 909.5 & 907.2 & - & $907.0^{*}$ \\
\hline Saponification index (mg KOH/g oil) (IAL-2008) & 180.6 & 179.4 & - & - \\
\hline Iodine value ( $\mathrm{g} \mathrm{I}_{2} / 100 \mathrm{~g}$ oil) (Wijs /IAL-2008) & 68.9 & 70.7 & - & - \\
\hline Water content (Karl Fischer) (mg/kg) (NBR 11348/ASTM D6304) & 876.6 & 632.0 & - & 630.2 \\
\hline Turbidity (NTU at $\left.20^{\circ} \mathrm{C}\right)($ HachTurbidimeter $2100 \mathrm{~N})$ & 64.1 & 12.6 & 31.1 & 2.1 \\
\hline Acidity index (mg KOH/g oil) (IAL-2008) & 8.8 & 20.5 & 18.1 & 0.2 \\
\hline
\end{tabular}

${ }^{*}$ Obtained by the densimeter method NBR 7148; ${ }^{* *}$ nd: not detected with the analytical method used. NBR: Brazilian Standards - Brazil (ABNT - Brazilian Association of Technical Standards); ASTM: American Standards - USA (American Society for Testing and Materials); IAL: Brazilian Standards of Institute Adolfo Lutz (IAL). Source: Pereira et al. (2016b).

Table 2. Profile of the fatty acids of the moringa oil by mechanical pressing and esterified.

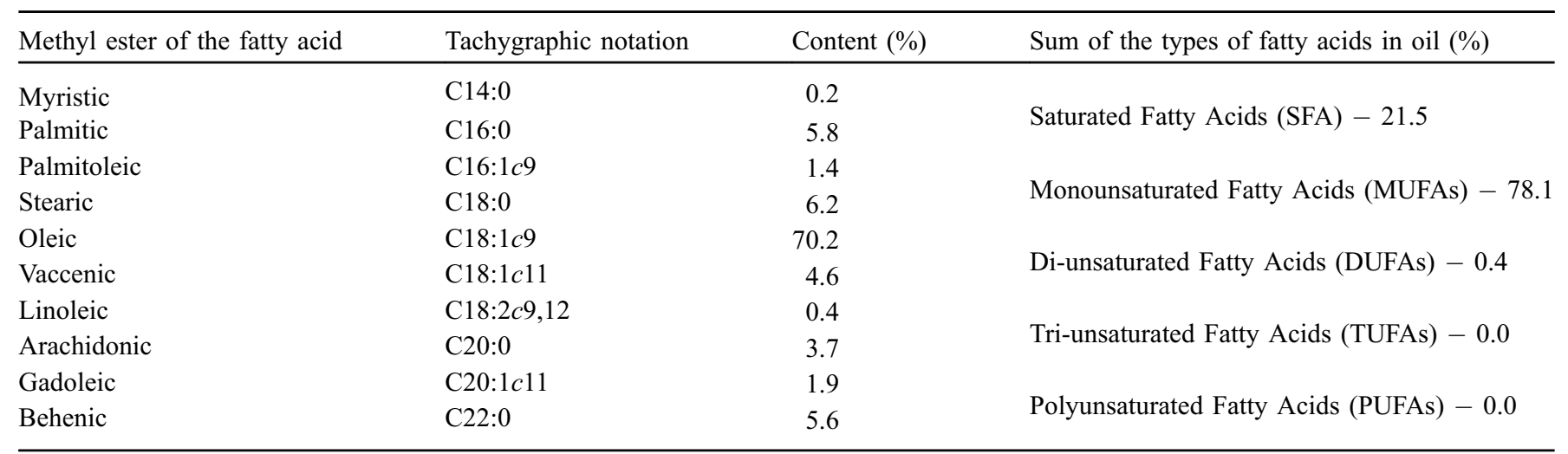


Kinematic viscosities obtained in this study (Tab. 1) for the moringa oils (crudes or purified) are higher than for the refined soybean oil $\left(32.6 \mathrm{~mm}^{2} \cdot \mathrm{s}^{-1}\right.$ at $\left.40^{\circ} \mathrm{C}\right)$. It is important to highlight that the presence of small quantities of residual solvent can influence the lowest viscosity result when compared to the one of pressing and also by the fact that the solvent removes soluble components in it. Comparing the viscosity of the purified mixed oil to the crude oils, the treatments increase this parameter in relation to the one obtained by solvent extraction, and reduce in relation to the one obtained by mechanical pressing (Pereira et al., 2016b).

Saponification index may serve as a subsidy for calculating the molar masses of saponifiable oils or fats through the use of volumetric acid-base analytical methodology of return. It can also serve as a comparative analytical resource to evaluate possible frauds of these materials with other foreign substances. The grease distribution of these materials is generally between 8 and 26 carbons with the possibility of inclusion of saturated and unsaturated carbon chains. The results of the study (Tab. 1) are within the classic interval (between 180 and $200 \mathrm{mg}_{\mathrm{KOH}} \cdot \mathrm{g}^{-1}$ ) for oleaginous vegetables or saponifiable animals, such as the soybean oil $\left(190.0 \mathrm{mg}_{\mathrm{KOH}} \cdot \mathrm{g}^{-1}\right)$ and beef tallow $\left(195 \mathrm{mg}_{\mathrm{KOH}} \cdot \mathrm{g}^{-1}\right)$ (Pereira et al., 2016b).

Iodine value is used to evaluate the structural characteristic in relation to the unsaturation of the glycerol esters chain of the oil. The results of the study (Tab. 1) are similar to some references of literature and below the soybean oil (120 and $141 \mathrm{gI}_{2} / 100 \mathrm{~g}$ ) and beef tallow (between 33 and $47 \mathrm{gI}_{2} / 100 \mathrm{~g}$ ). The higher this index, the more unsaturated and vulnerable to oxidative degradation the fatty material will be. It is recommended to evaluate the iodine value in the crude oil to avoid interferences of substances or conditions that can change the characteristics and analytical results (Pereira et al., 2016b).

Water contents (Tab. 1) were of $876.6 \mathrm{mg} \cdot \mathrm{kg}^{-1}$ (approximately $0.09 \%$ ) for the moringa crude oil by mechanical pressing, $632.0 \mathrm{mg} \cdot \mathrm{kg}^{-1}$ (approximately $0.06 \%$ ) by solvent extraction and $630.2 \mathrm{mg} \cdot \mathrm{kg}^{-1}$ (approximately $0.06 \%$ ) for the mixed purified oil. The results for the oil obtained by chemical extraction and for the purified oil were similar, suggesting that using a solvent treatment, neutralising reagents and heating improve the acceptable water levels of the material, though an intrinsic indication in the structure of the fatty material might maintain some residual. The values were below the ones acceptable for oil feedstock for biodiesel $(0.1 \%$ maximum humidity) or for other uses. The water present in the oils, even in small quantities, is a negative factor, favouring the hydrolysis reactions, oxidation and microbial degradation (Pereira et al., 2016b).

Peroxide index is associated to the oxidation reactions due to the oxygen's effect in the double bonds of the fatty acids present in the oil and intrinsically linked to the increase in the acidity index and vice versa. The values of this study (Tab. 1) correlate to the high acidity indexes. This index was evaluated comparing the crude oils of moringa with the refined soybean oil $\left(0.5 \mathrm{meqO} \mathrm{O}_{2} \cdot \mathrm{kg}^{-1}\right.$ oil - most used feedstock in Brazil to biodiesel and abundant use in food) and with an acceptable limit for edible crude oils (until $15 \mathrm{meqO} \mathrm{O}_{2} \cdot \mathrm{kg}^{-1}$ oil) and refined edible oils (until $10 \mathrm{meqO} \mathrm{O}_{2} \cdot \mathrm{kg}^{-1}$ oil), for the product acceptability with low oxidative depreciation. The values obtained were above the reference for soybean, but within the acceptable limit for vegetable oils for biodiesel production or food, cosmetic or medicinal use. The peroxide index for mixed purified oil was not detected with the methodology used indicating that the processes of degumming, neutralization, washing and drying removed the contaminants that can cause oxidation (Pereira et al., 2016b,c).

Turbidity, an analytic parameter not very common in studies regarding analytical characterizations of oils and fats, served to evaluate the changes in appearance of the moringa oils during the degumming, neutralization, washing and drying. The results of the study (Tab. 1) show that the chemical interactions with substances (extraction solvent or treatment reagents) promote the substantial reduction of turbidity caused by chemical species with no interest in the final composition of the purified oil, mainly if for used as biodiesel feedstock (Pereira et al., 2016b,c).

Acidity index measures the presence of free fatty acids (FFAs) generated by effects of the hydrolysis or oxidative and were considered high for crude oils (pressing, by solvent extraction and mixed oil), but the mixed purified (degummed, neutralized, washed and dried) presented acceptable conditions for various uses. The extractive method by solvent has a negative influence on the quality of the oil, explained by the heating and chemical interactions between the substances (oil and solvent) and confirmed with the results (Tab. 1) obtained in this study. The conditions of production and storage of the seeds, the expiration date, time of processing and ways of manipulation favour the increase of this index (negative aspect) (Pereira et al., 2016b).

The composition of the fatty acids present in the oil of the moringa seeds of this study (Tab. 2) and coming from various locations and regions of the world (Tsaknis et al., 1999; Lalas and Tsaknis, 2002; Abdulkarim et al., 2005; Rashid et al., 2008; Santana et al., 2010; Compaoré et al., 2011; Prados et al., 2012; Domínguez et al., 2017) are convergent (with highlighting for the oleic acid, monounsaturated with 18 carbon atoms and "cis" configuration, ranging from 67.9 to $78.0 \%$, with a mean of $72.95 \%$ ) overcoming the saturated acids. These results were obtained by chromatographic characterization and made it possible to calculate the molar mass of the moringa oil $\left(298.99 \mathrm{~g} \cdot \mathrm{mol}^{-1}\right)$ and of the biodiesel (892.99 g.mol ${ }^{-1}$ ) (Pereira et al., 2016a,b).

\subsection{Physical-chemical parameters of methyl biodiesel and productive yields}

Table 3 shows some results found for the biodiesel, obtained in bench scale and micro-scale. The results were compared with literature data and normative standards for the quality evaluation of biodiesel using the parameters: specific mass, kinematic viscosity and ester content (related to engine performance); acidity index (related to safety and fuel stability) and water content (related to impurity in the oil or purification failure on productive process) (Pereira, 2015).

The analytical parameters (Tab. 3) of this study, specific mass, kinematic viscosity and acidity index of the biodiesel produced are in accordance with ANP and EN standards, showing an easy adaptation to these, depending on the operational cares and treatments used. The ester and water 
F.S.G. Pereira et al.: OCL 2018, 25(1), D106

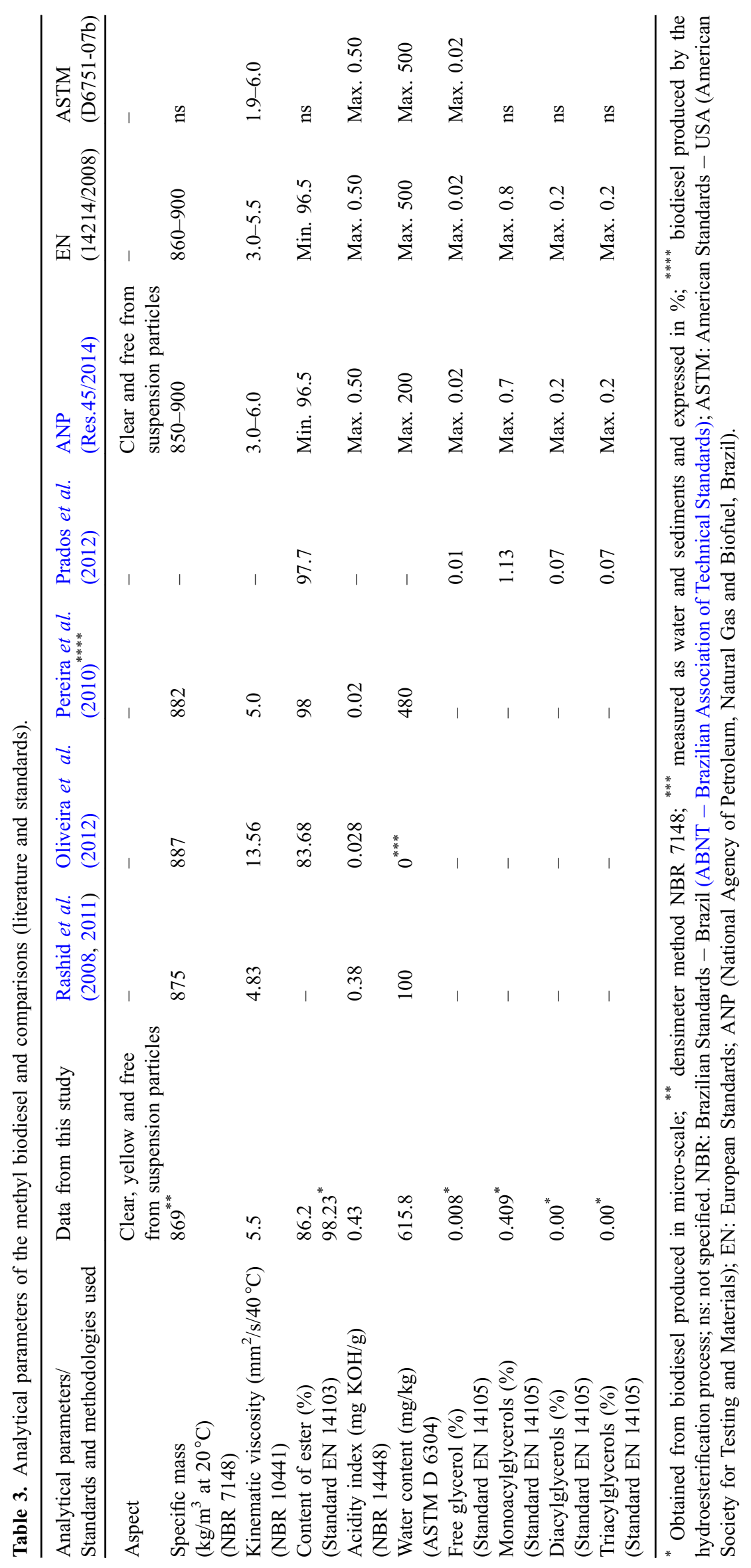

Page 6 of 11 
contents in turn did not reach the acceptable limits in the normatives, demanding greater operational cares in the production, mainly in bench scale. At micro-scale, the ester content exceeds the acceptable limits of ANP and EN regulations. The major operational challenge is to improve bench scale, pilot scale and industrial production, in purity similar to micro-scale conditions, for biodiesel to meet regulatory requirements (Pereira, 2015).

The high quantity of the oleic acid (Tab. 2) in the fatty structure of the moringa oil provides good flowability and less capacity for oxidative deterioration or rancidity, being quite versatile in biodiesel production (Tsaknis et al., 1999). Atabani et al. (2013) obtained the oxidative stability (Rancimat at $110^{\circ} \mathrm{C}$ ) of $41.75 \mathrm{~h}$ (for moringa oil) and $6.09 \mathrm{~h}$ (for soybean oil), showing this trend in oil stability as a feedstock and subsequent maintenance in the resulting biodiesel (methyl esters), with values of $12.64 \mathrm{~h}$ for the moringa biodiesel and $4.08 \mathrm{~h}$ for the soybean biodiesel. Silva et al. (2015) found $7.63 \mathrm{~h}$ for biodiesel (B100) from bovine tallow. Melo (2010) obtained $7.6 \mathrm{~h}$ for the oxidative stability of moringa oil using the same type of equipment and test conditions. Tsaknis et al. (1999) determined the values of oxidative stability (Rancimat at $120^{\circ} \mathrm{C}$ ) before and after the degumming of the moringa oil by cold pressing $(34.1$ and $18.9 \mathrm{~h})$, by solvent extraction with hexane (36.8 and $10.8 \mathrm{~h}$ ) and extraction with chloroform/ methanol solvent mixture $(46.2$ and $16.5 \mathrm{~h})$, respectively, showing that the stability of the crude oil is about the double or triple of that of the degummed oil, explained by the presence of large amount of tocopherols in its composition (Pereira, 2015).

According to Waynick (2005), the oxidative stability of a saponifiable oleaginous can be evaluated through the primary oxidation potential using the oxidability index (OI) by the equation:

$\mathrm{OI}=[(0.02 \times \%$ oleic $)+(\%$ linoleic $)+(2 \times \%$ linolenic $)] / 100$.

Calculating this index for the moringa oil (Tab. 2) of this study $(\mathrm{OI}=0.019)$ and for the most used feedstocks in Brazil for the production of biodiesel: soybean oil $(\mathrm{OI}=0.67)$ and bovine tallow $(\mathrm{OI}=0.042)$, one can make important considerations. The OI of soybean oil (about 35 times) and that of sebum (about 2 times) are higher than that of moringa oil. These results suggest a higher oxidative stability for moringa oil in relation to soybean oil and bovine tallow, confirmed in the experimental data of the previous paragraph, for the oils and derivate biodiesel (Pereira, 2015). The higher the value of OI, but susceptible to oxidative deterioration will be the fatty material, measured through oxidative stability, being the Rancimat method, one of the analytical techniques employed (Waynick, 2005).

\subsection{Energetic parameters of the biomasses investigated of moringa}

The Table 4 shows the experimental results of this study for parameters: gravimetric moisture, water content, ash content and calorific values of moringa biomasses and three classic energetic references: dry firewood on the air, sugarcane bagasse and coconut husks (Pereira, 2015; Pereira et al., 2015).

The parameters, moisture content, ash content and higher calorific value (HCV) or lower (LCV), are fundamental in the previous analysis of the use of biomass as an energy source or renewable fuel. Moisture and ash contribute negatively to the calorific value or energy stored in the fuel. The evaluation of the biomasses of study (Tab. 4), for the possible application in furnaces and boilers, mainly in the production of biodiesel, compare with reference values maximum acceptable of $5 \%$ in ash content and 20\% moisture content (Garcia, 2002; Nogueira and Lora, 2003) for direct burning as solid fuel. The lower these values, better the fuel performance. Wood is widely used in the world, sugar cane bagasse in generation of steam and electricity, mainly sugar and alcohol industry and coconut husks as a great energetic potential and still little explored in this use. The analytical results aiming at the energetic aspect of the samples, compared with the references, show good perspectives for the biomasses originated from the moringa (Pereira, 2015; Pereira et al., 2015).

The solid biomasses investigated (Tab. 4), crude seeds, husks, grains and cakes are interesting biofuels due to the analytical parameters found, compared with the suggested (maximum of $5 \%$ ash and $20 \%$ humidity), even better than sugarcane bagasse, well consolidated in this application. However, in this application the seed husks have the disadvantage that they are constituted of very light material. For this application it is recommended to increase their density through the production of pellets or briquettes to improve performance as alternative renewable fuel, but they are still energetically favorable. The oleaginous grains present good results with stored energy about 2 times in relation to the dry firewood on the air and 3 times that of sugarcane bagasse, but its use is more rational for oil extraction and pie production as co-products. Cakes of the grains present surprising analytical results when compared to reference values, since they combine the three analytical parameters that are very characteristic and suitable to be used as renewable fuels in technological processes of combustion or direct burning. They can be better adapted for this application through isolated densification or together with the seed husks in defined proportions (Pereira, 2015; Pereira et al., 2015).

Liquid biomasses (crude oils, purified oil and methyl biodiesel) compared to solid references are potential biofuels and are easier to handle due to their physical state. They have average moisture well below the tolerance proposed by Garcia (2002) and Nogueira and Lora (2003) and despicable ash content in this comparison. The lower calorific values are very high (between 36.88 and $37.13 \mathrm{MJ} / \mathrm{kg}$ ) for oils and $37.53 \mathrm{MJ} / \mathrm{kg}$ for methyl biodiesel. From the point of view of energy per kilogram of fuel (higher or lower calorific value), methyl biodiesel has values very close to the vegetable oil used as its raw material, but both lower than the mineral diesel oil of $46.65 \mathrm{MJ} / \mathrm{kg}$ (Moser, 2009). However, calorific power is not the only parameter to portray the energy efficiency of a fuel. Singh and Singh (2010), report that the cetane content of mineral diesel is between 40 and 55 while for biodiesel (B100) between 48 and 65 . The calculated value for cetane index of the biodiesel of this study was 58.2, ratifying the interval proposed by Singh and Singh (2010) and larger than diesel oil. The high cetane index provides a better burning of the biodiesel in a compression engine than the mineral diesel itself, and is less environmentally damaging due to releases of combustion gases free of aggressive sulfur oxides (Knothe et al., 2005). Another 
F.S.G. Pereira et al:: OCL 2018, 25(1), D106

Table 4. Results of the energetic analysis of the samples studied and of three classic references.

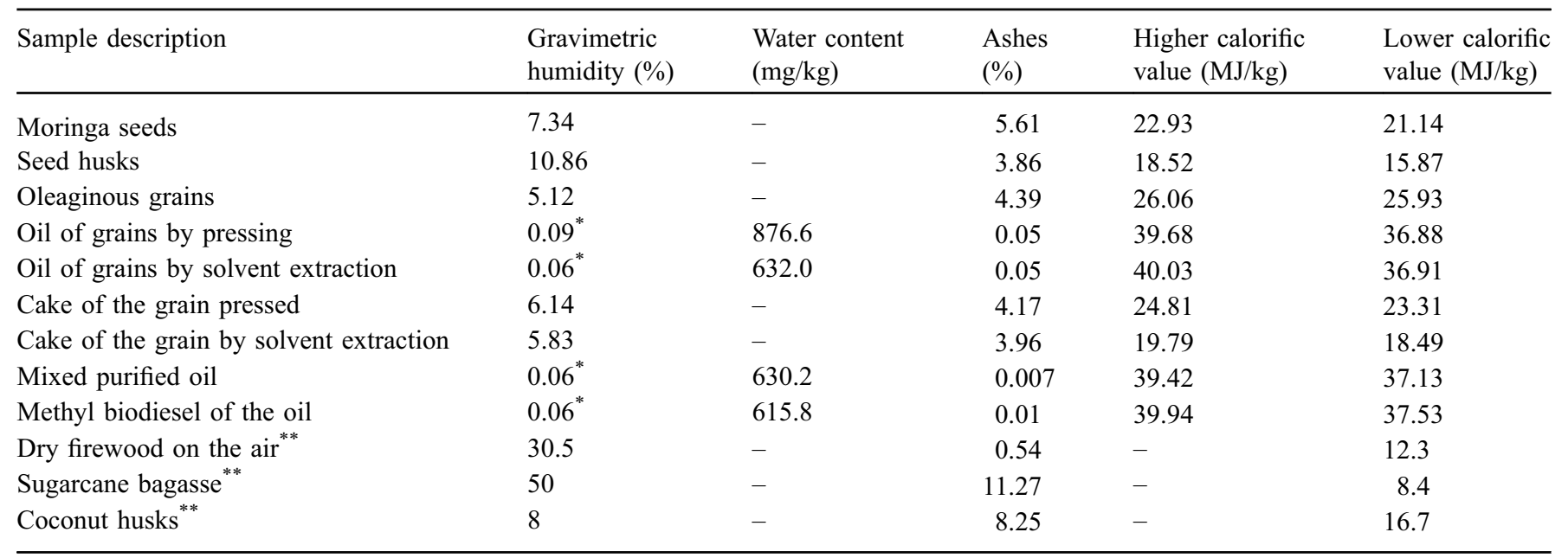

${ }^{*}$ Calculated based on the water content result obtained by the Karl Fischer method shown in this table; ${ }^{* *}$ data extracted from Nogueira and Lora (2003). Source: Pereira (2015); Pereira et al. (2015).

relevant factor for the biodiesel of moringa oil is its oxidation stability. Atabani et al. (2013) obtained the oxidative stability (Rancimat at $110^{\circ} \mathrm{C}$ ) of $12.64 \mathrm{~h}$ for the methyl biodiesel of the moringa oil, surpassing by 1.6 times (minimum of $8 \mathrm{~h}$ ) the value endorsed by resolution n.45/2014 of the ANP and $4.08 \mathrm{~h}$ for soybean biodiesel (below the minimum recommended by the ANP). Silva et al. (2015) found $7.63 \mathrm{~h}$ for biodiesel (B100) of bovine tallow, slightly below the minimum recommended by ANP. It can be seen from the experimental values that moringa biodiesel is an optimistic proposal in terms of oxidative stability when compared to soybean oil and bovine tallow; the most used raw materials in Brazil for this purpose (Pereira, 2015; Pereira et al., 2015).

\subsection{Quantifications of biomasses produced from seeds}

The traditional and less optimistic analysis of the biodiesel production chain from the moringa seeds shows that the husks, the cakes and the glycerin are considered as residues. However, due to the values of the upper and lower calorific value (Tab. 4) of the husks and cakes (agro-industrial residues), one can add value by using them as energy generators directly in the production of biodiesel or to provide energy for other productive processes associated. Glycerin, at a minimum, can be used as a binder in the production of briquettes in this sustainable chain and its surplus, sold to add value to the chain and reduce production costs (Pereira, 2015).

Assuming a $100 \mathrm{~kg}$ processing of seeds and their derivatives based on the experimental values obtained from husks, oleaginous grains, oil (solvent extraction), cake and biodiesel (homogeneous alkaline transesterification), according to the methodologies, quantifications and calculations, the data shown in Figure 2 can be established (Pereira, 2015).

The predicted theoretical amount of methyl biodiesel was calculated as follows: $1 \mathrm{~mol}$ of the moringa oil produces $3 \mathrm{~mol}$ of methyl esters (biodiesel) and $1 \mathrm{~mol}$ of glycerol. The stoichiometric molar ratios and the molar masses obtained for the oil and the methyl biodiesel provided the following ratios: $1 \mathrm{~mol} \times 892.99 \mathrm{~g} / \mathrm{mol}$ will produce $3 \mathrm{~mol} \times 298.99 \mathrm{~g} / \mathrm{mol}$. Then " $40 \mathrm{~g}$ " of the oil will produce " $\mathrm{X}$ "; $\mathrm{X}=40 \mathrm{~g} \times 3 \mathrm{~mol}$ $\times 298.99 \mathrm{~g} / \mathrm{mol} / 1 \mathrm{~mol} \times 892.99 \mathrm{~g} / \mathrm{mol}=40.18 \mathrm{~g}$ of predicted biodiesel. The quantity of purified biodiesel (pb) experimental (separate, neutral and washed) found by weighing and calculated was $34.5099 \mathrm{~g}$. The yielding after purification is calculated as: $\mathrm{Y}_{\mathrm{pb}}=(34.5099 \mathrm{~g} / 40.18 \mathrm{~g}) \times 100=85.89 \%$. The quantity of brute glycerin (impure glycerol phase) can be calculated by difference through the $\mathrm{Y}_{\mathrm{gb}}=100-\mathrm{Y}_{\mathrm{pb}} \quad(\%$ purified biodiesel) ratio, that is: $\mathrm{Y}_{\mathrm{gb}}=100.0-85.89=14.11 \%$. The ester (purity) content determined by GC/MS was $86.2 \%$ (bench scale) and the actual yield (converted oil) in the purified biodiesel in ester (pbe) calculated from: $\mathrm{Y}_{\mathrm{pbe}}=(85.89 \times 86.2) /$ $100=74.04 \%$ (Pereira, 2015).

Analyzing Figure 2 and the data in Table 4, it can be concluded that seeds, grains, seed husks, oil, cakes and biodiesel can be used as renewable biofuels. Of these, the most promising is biodiesel (potential substitute of petroleum diesel, in pure form (B100) or in mixture with fossil fuel) for its characteristics of renewability, high cetane number, less environmental impact, among others. In addition to biodiesel, cakes and seed husks as alternative solid fuels, especially if they are densified separately or together in the production of briquettes. It is possible to increase biodiesel productivity even further by using seeds with oil content of $45 \%$ (Banerji et al., 2009 ), reaching $30.4 \mathrm{~kg}$ of biodiesel per $100 \mathrm{~kg}$ of seeds in the same conditions as mentioned above, a significant increase, about $52 \%$ in relation the $19.49 \mathrm{~kg}$ obtained and more than $30 \%$ in relation to the initial seeds $(100 \mathrm{~kg})$ (Pereira, 2015).

\subsection{Perspectives of moringa crop compared to soybean}

Table 5 presents a comparison between moringa and soybean (agricultural feedstock most used in Brazil and in some countries), with data from this study (Pereira, 2015) and 


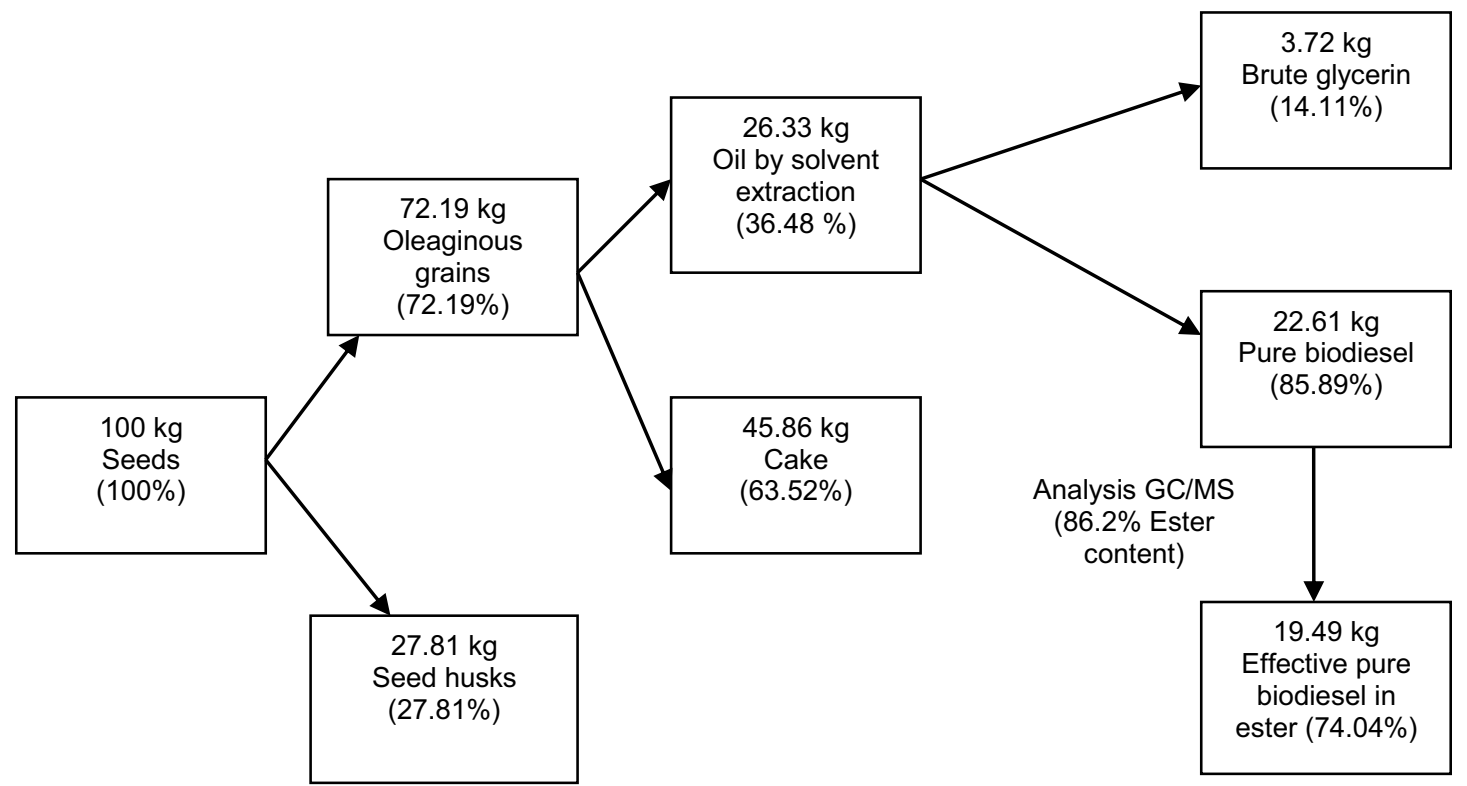

Fig. 2. Quantifications of biomasses produced from seeds.

Table 5. Comparison of moringa and soybean as oleaginous cultures for biodiesel.

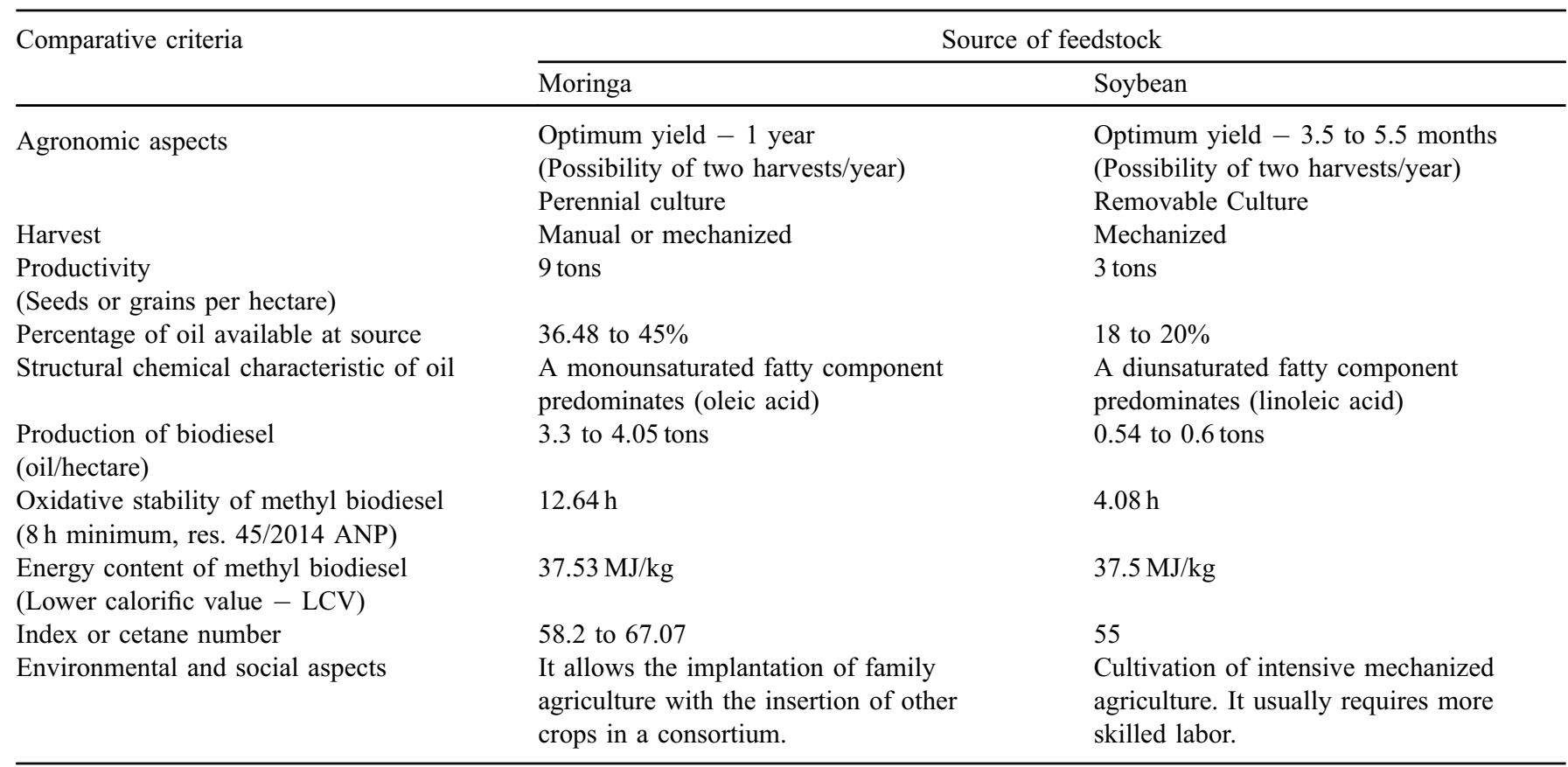

of some references (Rashid et al., 2008; Banerji et al., 2009; Moser, 2009; Singh and Singh, 2010; Bunce et al., 2011; Atabani et al., 2013; EMBRAPA, 2015).

Observing the information in Table 5, some considerations can be made (Pereira, 2015).

Soybean crop is more adequate in flat areas with mechanized system, both in planting and harvesting. Requires, soil control, adequate climate, irrigated system or regular rainfall. The planting is of the direct type with sowing. The culture of the moringa can be made using flat or irregular areas (slopes). Not demanding in terms of soil, climate and rainfall. The planting can be done by seeds, cuttings or by seedlings previously cultivated in nurseries. The productive exploitation of the moringa admits, at least 5 years with classic agricultural pruning and care.

Average productivity per hectare of the moringa can reach 9 tons while the soybean of 3 tons and the average percentage of oil of $40.74 \%$ and $19 \%$, respectively.

Moringa oil is more stable (the major component is oleic acid, with more than $70 \%$ participation, more stable to oxidation) than soybean oil (the major component is linoleic acid, with approximately $55 \%$ of the composition, which is more vulnerable to oxidation), carrying this greater or lesser stability characteristic for its derived biodiesel. 
Production of biodiesel per hectare was calculated indirectly using the ratio (oil percentage $\times$ seed production), because in the transesterification, the molar ratio of oil: biodiesel is the same, that is, $1 \mathrm{~mol}$ of triacylglycerol, produces $3 \mathrm{~mol}$ of esters, coming of this fat matrix.

Moringa biodiesel is more stable (oxidative stability about 3 times greater than soybean biodiesel and 1.5 times above the ANP recommended condition). Soybean biodiesel is below the ANP recommendation (about half of the recommended oxidative stability - Res. 45/2014).

Therefore, in view of the relevant aspects raised in the Table 5, Moringa oleifera could serve as a new agricultural crop for the expansion of the use of renewable sources in tune with the objectives of the United Nations (Sustainable Energy for All, IEA, 2015), mainly focusing its implementation in the northeast regions and in northern Brazil and in regions of the world with semi-arid climate and more difficult conditions, to promote economic, social and environmental sustainability.

\section{Conclusions}

Moringa oleifera seeds produced directly or indirectly the biomasses: seed husks, oils, cakes (pies) and methyl biodiesel. The extractive yield of the moringa oil $(11.36 \%$ by pressing and $36.48 \%$ by solvent, with a mean of $23.92 \%$ ) is feasible even with artisanal resources, being ratified by the literature. Moringa oil has a fatty acid profile of $21.5 \%$ saturated and $78.5 \%$ unsaturated, with predominance of oleic acid (greater than $70 \%$ ). Moringa oil (crude or purified) has interesting sensory and physico-chemical characteristics such as mild odor, pleasant appearance and good tactile fluidity, being excellent raw material for biodiesel due to its content in the seeds, simple extraction processes and good chemical stability to oxidation. Methyl biodiesel obtained had a specific mass of $869 \mathrm{~kg} \cdot \mathrm{m}^{3}\left(20^{\circ} \mathrm{C}\right)$, kinematic viscosity of $5.5 \mathrm{~mm}^{2} \cdot \mathrm{s}^{-1}\left(40^{\circ} \mathrm{C}\right)$ and acidity index of $0.43 \mathrm{mg} \mathrm{KOH} \cdot \mathrm{g}^{-1}$ convergent with the resolution 45/2014 of ANP and EN, ester content $86.2 \%$ (but $98.23 \%$ obtained in microscale, ratifying the viability of the production method) and water content of $615.8 \mathrm{mg} / \mathrm{kg}$, easily corrected for adjustments in experimental procedures. The solid biomasses of the moringa chain (seed husks and cakes) have high energy potentials (calorific value between 15.87 and $23.31 \mathrm{MJ} / \mathrm{kg}$ ) for the production of briquettes or ecological firewood, as well as the simplified briquetting technology. The culture of the moringa was compared to that of the soybean in agricultural and biodiesel production perspectives, with great optimistic expectations for the moringa. The results indicate that the proposed energy applications are viable, showing the versatility of Moringa oleifera Lamarck due to its good acclimatization to Brazil and regions with semi-arid climate or similar and not very fertile soils.

\section{Conflict of interest}

The authors declare that they have no conflicts of interest in relation to this article.

\section{References}

Abdulkarim SM, Long K, Lai OM, et al. 2005. Some physicochemical properties of Moringa oleifera seed oil extracted using solvent and aqueous enzymatic methods. Food Chem 93: 253263.

ABNT. 2015. Associação Brasileira de Normas Técnicas. Normas diversas. Available from http://www.abnt.org.br/normalizacao/ lista-de-publicacoes/abnt (last consult: 2017/29/06).

Ahmad M, Khan MA, Zafar M, Sultana S. 2013. Practical Handbook on Biodiesel Production and Properties. Boca Raton: Taylor \& Francis Group, LLC.

Amaya DR, Kerr WE, Godoi HT, Oliveira AL, Silva FR. 1992. Moringa: Hortaliça Arbórea Rica em Beta-Caroteno. Hortic Bras, Brasilia 10(2): 126.

ANP. 2014. Agência Nacional do Petróleo, Gás Natural e Biocombustíveis. Resolução n.45/2014 ANP sobre o biodiesel em 25.08.2014. Available from http://nxt.anp.gov.br/NXT/gate way.dll? $\mathrm{f}=$ templates $\& \mathrm{fn}=$ default.htm\&vid=anp: $10.1048 / \mathrm{enu}$ (last consult: 2017/29/06).

Anwar F, Bhanger MI. 2003. Analytical characterization of Moringa oleifera seed oil grown in temperate regions of Pakistan. J Agric Food Chem 51: 6558-6563.

Aransiola EF, Ojumu TV, Oyekola OO, Madzimbamuto TF, IkhuOmoregbe DIO. 2014. A review of current technology for biodiesel production: State of the art. Biomass Bioenergy 61:276297. Available from http://dx.doi.org/10.1016/j.bio mbioe.2013.11.014.

Araújo MS. 2010. Manejo de Espécies Florestais para Produção de Madeira, Forragem e Restauração de Áreas Degradadas. Caicó: Emparn.

Atabani AE, Mahlia TMI, Masjuki HH, et al. 2013. A comparative evaluation of physical and chemical properties of biodiesel synthesized from edible and nonedible oils and study on the effect of biodiesel blending. Energy 58: 296-304. Available from http:// dx.doi.org/10.1016/J.ENERGY.2013.05.040.

Banerji R, Bajpai A, Verma SC. 2009. Oil and fatty acid diversity in genetically variable clones of Moringa oleifera from India. J Oleo Sci 1: 9-16.

Bunce M, Snyder D, Adi G, et al. 2011. Optimization of soy-biodiesel combustion in a modern diesel engine. Fuel 90: 2560-2570.

Cáceres A, Freire V, Girón LM, Avilés O, Pacheco G. 1991. Moringa oleifera (Moringaceae): Etnobotanical studies in Guatemala. Econ Bot 45(4): 522-523.

Compaoré WR, Nikièma PA, Bassolé HIN, et al. 2011. Chemical composition and antioxidative properties of seeds of Moringa oleifera and pulps of Parkia biglobosa and Adansonia digitata commonly used in food fortification in Burkina Faso. Curr Res $J$ Biological Sci 3(1): 64-72.

Crosby GW. 2007. Soilless culture of moringa (Moringa oleifera Lam.) for the production of fresh biomass. Doctoral Dissertation, University of Massachusetts Amherst.

Domínguez YD, García DT, Pérez LG, et al. 2017. Extraction and characterization of oil from Moringa oleifera for energy purposes. Wulfenia Journal 24(5).

EMBRAPA. 2015. Empresa Brasileira de Pesquisa Agropecuária. Cultivo de soja. Available from https://www.embrapa.br/soja/ cultivos/soja1 (last consult: 2017/29/06).

Fahey JW. 2005. Moringa oleifera: A review of the medical evidence for its nutritional, therapeutic, and prophylactic properties. Part 1. Trees Life J 1: 1-15.

Foidl N, Mayorga L. 2000. Cultivo De Marango Para La Producción De Proteínas Y Energía, El Nuevo Diário, Manágua, Nicarágua. 
Foidl N, Makkar HPS, Becker, K. 2001. The potential of Moringa oleifera for agricultural and industrial uses. Available from $\mathrm{http}: / /$ miracletrees. org/moringa-doc/the_potential_of_moringa_oleifera_for_agricultur al_and_industrial_uses.pdf (last consult: $2014 / 10 / 10$ ).

Fuglie LJ, ed. 2001. The Miracle tree - Moringa oleifera: Natural nutrition for the tropics. Training Manual. Dakar, Senegal: Church World Service.

Garcia R. 2002. Combustíveis e combustão industrial, 1a. ed. Rio de Janeiro, RJ: Interciência.

Goja A. 2013. Physico-chemical properties of oil produced from Moringa oleifera, Jatropha curcas and Carthamus tinctorius $L$ seeds. Sudão. Int J Adv Res 1(4): 181-187.

HDRA. 2002. The organic organisation. Moringa oleifera a multipurpose tree. Available from http://miracletrees.org/moringa-doc/ all_about_moringa_the_wonder_tree.pdf(last consult: 2014/10/10).

IAL. 2008. In stituto Adolf Lutz. Métodos físico-químicos para análise de alimentos. (4nd. ed. - 1a. ed. dig.), São Paulo, SP: Editora do IAL. Available from http://www.crq4.org.br/sms/files/ file/analisedealimentosial 2008.pdf (last consult: 2014/10/10).

IEA. 2015. International Energy Agency and the World Bank. "Sustainable Energy for All 2015-Progress Toward Sustainable Energy" (June), World Bank, Washington, DC. Available from https://openknowledge.worldbank.org/handle/10986/22148 (last consult: 2017/29/06).

Jahn SAA. 1989. Proper use Moringa oleifera for food and water purification - Selection of clones and growing of annual shortstem. Pflanzenzucht 4: 22-25.

Kegl B, Kegl M, Pehan S. 2013. Green diesel engines - biodiesel usage in diesel engines. London: Springer-Verlag.

Knothe G, Gerpen JV, Krahl J. 2005. The biodiesel handbook. Champaign, Illinois: AOCS Press.

Lalas S, Tsaknis J. 2002. Extraction and identification of natural antioxidant from the seeds of the Moringa oleifera tree variety of Malawi. J Am Oil Chem Soc 79: 677-683.

Marchetti JM. 2012. A summary of the available technologies for biodiesel production based on a comparison of different feedstock's properties. Process Saf Environ Prot 90: 157-163.

Melo MAMF. 2010. Avaliação das Propriedades de Óleos Vegetais visando a Produção de Biodiesel. Masters dissertation in portuguese, Universidade Federal da Paraíba.

Morton JF. 1991. The horseradish tree, Moringa pterygosperma (Moringaceae) - a boon to arid lands? Econ Bot 45(3): 318-333.

Moser BR. 2009. Biodiesel production, properties, and feedstocks. In Vitro Cell Dev Biol - Plant 45: 229-266.

Nogueira LAH, Lora EES. 2003. Dendroenergia: fundamentos e aplicações, 2nd ed. Rio de Janeiro: Interciência.

Oliveira DS, Fonseca XDS, Farias PN, et al. 2012. Obtenção do biodiesel através da transesterificação do óleo de Moringa oleifera Lam. HOLOS 1: 49-61.

Parrotta JA. 2009. Moringa oleifera LAM., 1785. ENZYKLOPÄDIE DER HOLZGEWÄCHSE - 40. Erg. Lfg. 6/05. 2009. Disponível em: http://www.fs.fed.us/research/publications/misc/ 63355_2005_\%20Parrotta\%20Moringa\%20oleifera.pdf (last consult: $2 \overline{0} 17 / 29 / 06)$.

Pereira FSG. 2015. Viabilidade sustentável de biomassas de Moringa oleifera para produção de biodiesel e briquetes. Tese de doutorado, Universidade Federal de Pernambuco - UFPE.
Recife, PE, Brasil. Available from http://repositorio.ufpe.br:8080/ handle/123456789/15071.

Pereira DF, Vasconcelos VM, Vieira AC, Aranda DAG, Silva GF. 2010. Produção de biodiesel a partir da hidroesterificação do óleo de moringa. II ENCONTRO NACIONAL DE MORINGA. Brasil: Aracaju, Sergipe.

Pereira FSG, Silva AMRB, Galvão CC, et al. 2015. Moringa oleifera as sustainable source for energetic biomass. Int J Chem 7(2): 177185. Available from http://dx.doi.org/10.5539/ijc.v7n2p177.

Pereira FSG, Brito Neto EX, Wei S, et al. 2016a. Produção de Biodiesel Metílico com Óleo Purificado de Moringa oleifera Lamarck. $R V Q$ 8(3): 873-888. Available from http://dx.doi.org/ 10.5935/1984-6835.20160063.

Pereira FSG, Galvão CC, Lima VF, et al. 2016b. The versatility of the Moringa oleifera oil in sustainable applications. OCL 23(6): A601. Available from http://doi.org/10.1051/oc1/2016027.

Pereira FSG, Schuler ARP, Silva AMRB, et al. 2016c. Turbidity and acidity as monitoring parameters in the purification of Moringa oleifera oil for biodiesel production. Am Chem Sci J 16(3): 1-9. Available from http://doi.org/10.9734/ACSJ/2016/28799.

Pereira RN, Pereira FSG, Galvão CC, et al. 2016d. Biodiesel from residual oils: Less Environmental impact with sustainability and simplicity. Chem Sci Int J 17(3): 1-14. Available from http:// www.sciencedomain.org/abstract/16850.

Prados CP, Rezende DR, Batista LR, Alves MIR, Antoniosi Filho NR. 2012. Simultaneous gas chromatographic analysis of total esters, mono-, di- and triacylglycerides and free and total glycerol in methyl or ethyl biodiesel. Fuel 96: 76-481. Available from http:// dx.doi.org/10.1016/j.fuel.2011.11.060.

Ramachandran C, Peter KV, Gopalakrishnan PK. 1980. Drumstick (Moringa oleifera) a multipurpose indian vegetable. Econ Bot 34: 276-283.

Rashid U, Anwar F, Moser BR, Knothe G. 2008. Moringa oleifera oil: A possible source of biodiesel. Bioresour Technol 99: 8175-8179.

Rashid U, Anwar F, Ashraf M, Saleem M, Yusup S. 2011. Application of response surface methodology for optimizing transesterification of Moringa oleifera oil: biodiesel production. Energy Convers Manag 52: 3034.

Santana CR, Pereira DF, Araújo NA, et al. 2010. Caracterização físicoquímica da moringa (Moringa oleifera Lam). Revista Brasileira de Produtos Agroindustriais, Campina Grande 12: 55-60.

Schuler ARP, Pereira FSG, Lima VF, Carvalho SLBV, Sobral AD. 2016. Chromato-graphic Characterization of potential feedstocks for biodiesel production. Chem Sci Int J 17(2): 1-10. Available from http://www.sciencedomain.org/abstract/16474.

Silva AAL, Santos AGD, Souza L, Caldeira VPS, Luz Junior GE, Araújo AS. 2015. Síntese e Caracterização de Biodiesel de Sebo Bovino e de sua Mistura B10. Orbital: Electron J Chem 7(1).

Singh SP, Singh D. 2010. Biodiesel production through the use of different sources and characterization of oils and their esters as the substitute of diesel: A review. Renew Sustainable Energy Rev 14: 200-216.

Tsaknis J, Lalas S, Gergis V, et al. 1999. Characterization of Moringa oleifera variety Mbololo seed oil of Kenya. J Agric Food Chem 47: 4495-4499.

Waynick JA. 2005. Characterization of biodiesel oxidation and oxidation products. Available from http://www.nrel.gov/vehicle sandfuels/npbf/pdfs/39096.pdf (last consult: 2017/29/06).

Cite this article as: Pereira FSG, de Sobral AD, da Silva AMRB, da Rocha MAG. 2018. Moringa oleifera: a promising agricultural crop and of social inclusion for Brazil and semi-arid regions for the production of energetic biomass (biodiesel and briquettes). OCL 25(1): D106. 